\title{
POSSIBLE PROTECTIVE EFFECT OF ALPHA LIPOIC ACID AGAINST RICIN INDUCED HEPATOTOXICITY IN ADULT MALE ALBINO RATS
}

\author{
Amira A. Wahdan*and Naglaa Sarhan** \\ Departments of Forensic Medicine and Clinical Toxicology ${ }^{1}$ and Histology ${ }^{2}$, Faculty of \\ Medicine, Tanta University
}

\begin{abstract}
:
Introduction: Ricin is one of the most potent and deadly plant toxins known. It induces oxidative stress and was exploited as a poison for bioterrorism due to its characters. Developing an effective antidote for ricin toxicity becomes a reliable way against its potential biothreat. Alpha lipoic acid (ALA) being an ideal antioxidant, was chosen as protection against ricin toxicity. Aim of the work: The current study was carried out to confirm the hepatotoxic effect of ricin using the electron microscope (EM) and to assess the potential protective effect of ALA against ricin hepatotoxicity and lethality. Material and methods: The current study was conducted on 60 adult male albino rats. Rats were divided into four groups. The first group (10 rats) was used as control group. Group II (10 rats) was injected with ALA $(100 \mathrm{mg} / \mathrm{kg}$ intraperitoneal). Group III (20 rats) was injected once with ricin $(25 \mathrm{ug} / \mathrm{kg}$ subcutaneous). Group IV was injected with ALA (100 mg/kg) 15 minute prior to and immediately after ricin injection. Survival time was recorded and liver samples were taken for examination under EM. Results: Injection of ALA together with ricin significantly prolonged the survival time of the rats in group IV more than those in group III. Electron microscopic examination of liver specimens obtained from group III revealed hepatocytes with either euchromatic nuclei, shrunken hyperchromatic nuclei or nuclei with marginated chromatin. Hugely dilated degranulated rough endoplasmic reticulum (RER), many lipid droplets and electron dense mitochondria were detected. Treatment of animals with ALA resulted in less ultra structure damage. The hepatocytes showed either euchromatic nuclei or nuclei with marginated chromatin. Their cytoplasm exhibited slightly dilated RER, electron dense mitochondria and some vacuoles. Conclusion: It was concluded that ricin is a hepatotoxic substance causing ultra structure damage. Furthermore, ALA proved to be beneficial in prolonging the survival time and decreasing the toxic effect of ricin on the liver. Recommendations: Further studies are recommended to detect the underlying mechanism of ricin hepatotoxicity and to find more protective substances against ricin toxicity
\end{abstract}

Key words: Ricin, Alpha lipoic acid, hepatotoxicity, Electron microscope

\section{INTRODUCTION}

Ricin is a natural product extracted from the castor bean of Ricinus communis. This plant is distributed all over the world. Ricin is one of the most potent and deadly plant toxins known.
It belongs to a family of Type II Ribosome inactivate proteins (RIPs) that are able to kill eukaryotic cells (Albretsen, et al., 2000; Zhang, et al., 2015). It has an extra ordinary toxicity; a single molecule can halt the action of 
2000 ribosomes per minute, which leads to rapid cell death making ricin a potential weapon for bioterrorism (Doan, 2004; Schep, et al., 2009; Balali-Mood, et al., 2013). Since 1993, ricin has been designated as a Schedule 1 chemical under the terms of the 1993 Chemical Weapon Convention (David, et al., 2009).

Ricin physical state and dissemination method will determine its route of exposure in humans. It can be prepared as a crude impure plant extract, purified crystals, powder forms, or solubilized in liquids. Deliberate dissemination may occur as an aerosol, through addition to food or water, or by direct parenteral injection. Ricin poisoning is not contagious and person to person transfer is unlikely (Audi, et al., 2005).

Oral absorption is poor; the lethal oral dose in humans has been estimated to be 1 to $20 \mathrm{mg}$ of ricin $/ \mathrm{kg}$ of body weight. Absorption through intact skin is most unlikely to occur. The most hazardous routes of exposure are inhalation and injection (Bradberry, et al., 2003; Audi, et al., 2005). Ricin causes cell death through rapid irreversible inhibition of protein synthesis, therefore it is known to have diverse toxic effects on different visceral organs (Lord, et al., 1994; Buonocore, et al., 2011; Dong, et al., 2015; Zhang, et al., 2015).

The clinical features of ricin toxicity include nephrotoxicity, cardiotoxicity, central nervous system toxicity, hepatotoxicity and antifertility effects (Makonnen, et al., 1999; Kumar, et al., 2003). Furthermore, inhalation of small amounts of ricin can cause severe damage in the respiratory system and death (Audi, et al., 2005). In addition to reticulo-endothelial system damage including, fluid and protein loss, bleeding, edema and impaired cellular defense against endogenous toxins (Bradberry, et al., 2003).

Preliminary studies revealed that, ricin induces oxidative stress that results in lipid peroxidation, glutathione depletion, DNA single strand breaks and increased urinary excretion of carbonyl compounds. However, the mechanism involved in production of this oxidative stress is not fully under stood (Muldoon, et al., 1992; Muldoon, et al., 1994; Kumar, et al., 2003; Kumar, et al., 2007).

Oxidative degradation of lipids known as lipid peroxidation, and other oxidant mechanisms damage biological macromolecules specially the cell membrane ultimately leading to cell death (Yousef, et al., 2015). Oxidative stress, caused by an imbalance between free radicals production and their elimination by antioxidants, has been recognized as a central contributor to cellular injury and death (Mirakbari, 2015).

Alpha lipoic acid (ALA) is a popular cofactor of multi-enzymatic complexes which catalyzes oxidative decarboxylation of $\alpha$-ketoacids. It satisfies almost all characters of an "ideal antioxidant", being rapidly converted to its redox couple, dihydrolipoic acid (DHLA) in many tissues. Both ALA and DHLA effectively scavenge many types of free radicals and this antioxidant activity can be displayed in both lipid and aqueous-cell compartments (Singh, et al., 2014)

No specific treatment protocols exist for ricin exposures; treatment is largely symptomatic and supportive. Ricin is not amenable to dialysis and 
there is no currently available antidote (Audi, et al., 2005). Prophylactic immunization against ricin toxicity is a developing research that has great potential to produce a vaccine candidate for future application in humans (Muldoon and Stohs, 1994; Bradberry, et al., 2003; Zhang, et al., 2015).

Ricin was exploited as a poison for biological warfare and bioterrorism due to its characters of wide availability, easy accessibility, extraordinary toxicity, irreversible damage and lack of specific medical treatment (Millard and LeClaire, 2008; Balali-Mood, et al., 2013). Hence, developing an effective antidote becomes a reliable way against the potential biothreat. The current study was carried out to confirm the hepatotoxic effect of ricin using the electron microscope (EM) and to assess the potential protective effect of ALA against ricin hepatotoxicity and lethality.

\section{MATERIAL \& METHODS}

\section{1- Chemicals:}

Ricin:

Ricin was prepared from extract of ripe castor beans which were freshly picked at the peak of season (around mid August) from growing shrubs in villages surrounding Tanta city. All seeds were of the communis variety, with an average weight of 0.55 gram. One hundred and eighty seeds weighing 100 grams were freed from their hard thin shells. The seeds were crushed in a porcelain mortar into a thick powder. Saline was added gradually to make a fine emulsion until a total of $500 \mathrm{ml}$ of saline were added. The emulsion was kept in a large conical flask covered by cotton wool, put on a shaker for 24 hours at $4^{\circ} \mathrm{C}$ and was left to sediment for further 48 hours. A thick layer of oil was formed on top of the extract and white sediment in the bottom of the flask. The relatively clear layer in the middle was carefully aspirated by a large bore long needle and transferred into centrifuge tubes. They were centrifuged at 10000 r.p.m. for 20 minutes. The centrifuge process was repeated till the resultant fluid is clear one. Then, the final extract was filtered through filter paper. The extract was stored in sterile conical flasks $20 \mathrm{ml}$ capacity at $4^{\circ} \mathrm{C}$ till used (El tomy and Abo Hijleh, 1990).

As standard pure ricin was not available commercially due to its extreme toxicity, the ricin content of the prepared extract was determined by the fact that approximately $180 \mathrm{mg}$ of ricin was obtained from 100 gram of castor beans (Woo, et al., 1998). Castor oil seeds extract was given to the experimental animals in a dose of $25 \mu \mathrm{g} / \mathrm{kg}$ body weight subcutaneous (Kumar, et al., 2003).

\section{Alpha lipoic acid (ALA):}

It was purchased from EVA Pharma for Pharmaceutical and Medical Appliances, Egypt as $10 \mathrm{ml}$ ampoule contains $300 \mathrm{mg}$ ALA. It was given to the experimental animals in a dose of $100 \mathrm{mg} / \mathrm{kg}$ body weight intraperitoneal (Dulundu, et al., 2007).

\section{2- Experimental animals:}

This study was carried out on 60 adult male albino rats of Sprague dawly species. Their ages ranged from 2 to 4 months and their weights ranged from 125-150 grams. They were obtained from the animal house of the Faculty of Medicine, Tanta University, Egypt. During the study, the animals were kept in wire mesh cages with ad-libitum access to food and water. The room temperature was about $22-24{ }^{\circ} \mathrm{C}$ and 
the animals were exposed to $12: 12$ hours light dark cycles.

\section{3- Ethical considerations:}

1- Experimental procedures were performed according to the guide of care and the use of laboratory animals was approved by the Ethical Committee of Faculty of Medicine, Tanta University.

2- Fewer numbers of animals estimated to offer valid results were used.

3- Painless procedures were conducted with appropriate sedation to avoid pain and stress of the animals.

\section{4- Experimental design:}

The current study was carried out in Forensic Medicine \& Clinical Toxicology department, Tanta University. After one week of acclimatization to ensure normal growth and behavior. The animals were randomly assigned into four groups:

Group I (Control group): It included ten animals that were given $0.9 \%$ saline by intraperitoneal injection.

Group II (ALA treated group): It included ten animals that were given ALA $(100 \mathrm{mg} / \mathrm{kg})$ by intraperitoneal injection.

Group III (Ricin treated group): It included twenty animals; half of the animals were injected once by ricin solution subcutaneously in a dose of 25 $\mu \mathrm{g} / \mathrm{kg}$ body weight and served to test the survival time after ricin injection. The remaining animals were injected once by ricin solution in the same dose and were sacrificed 6 hours before the expected time of death.

Group IV (Ricin \& ALA treated group): It included twenty animals; half of the animals were given ALA $(100 \mathrm{mg} / \mathrm{kg}) 15$ minute prior to single injection by ricin solution in a dose of
$25 \mu \mathrm{g} / \mathrm{kg}$ body weight, then injected by ALA in the same dose immediately after ricin injection and served to test the survival time after ricin injection. The remaining animals were given ALA $(100 \mathrm{mg} / \mathrm{kg}) 15$ minute prior to single injection by ricin solution in a dose of $25 \mu \mathrm{g} / \mathrm{kg}$ body weight, then injected by ALA in the same dose immediately after ricin injection and were sacrificed 6 hours before the expected time of death.

\section{5- Sample collection:}

At the appropriate time of each group, animals were sacrificed by cervical dislocation then liver samples were taken from each animal. Liver samples were cut into small pieces 1 $\mathrm{mm}^{3}$ in size and immediately fixed in $2.5 \%$ of $0.1 \mathrm{M}$ phosphate buffered glutaraldehyde solution ( $\mathrm{pH} 7.4)$ at $4^{\circ} \mathrm{C}$ for 2 hours. After washing of the specimens with phosphate buffer for three times (5 min each time), they were post fixed in $1 \%$ phosphate buffered osmium tetra oxide at room temperature for $30 \mathrm{~min}$. Dehydration in a graded series of alcohol $(50,70,80$, 95 and $100 \%$ ) was carried out followed by washing and embedding in Epon.

Preparation of semithin sections (1um): The tissue embedded blocks were cut by ultramicrotome to be stained with toluidine blue for light microscopic examination.

Preparation of ultrathin sections (80-90 nm): The blocks were cut with ultramicrotome, stained with $2 \%$ uranyl acetate and lead citrate (Bozzola and Russel, 1999) and examined by a JEOL EM at EM Unit, Faculty of Medicine, Tanta University.

\section{6- Statistical Analysis:}

Data were analyzed using SPSS software statistical computer package version 20. Statistical analysis of 
survival time was conducted using independent sample $\mathrm{T}$ test. The results were presented as mean values \pm standard deviations (SD). A value of < 0.05 was accepted as statistically significant (Dawson-Saunders and Trapp, 2001)

\section{RESULTS}

1-Survival time results:

The survival time is the time that passed since the injection of ricin at a dose of $25 \mu \mathrm{g} / \mathrm{kg}$ body weight till death occurred. Injection of ALA together with ricin significantly prolongedthe survival time of rats in group IV more than those in group III (table 1).

Table (1): Survival time after ricin injection in Group III and IV

\begin{tabular}{|l|l|l|l|l|}
\hline Groups & $\begin{array}{l}\text { Minimum- } \\
\text { maximum (hours) }\end{array}$ & Mean \pm SD & \multicolumn{2}{|l|}{$\begin{array}{l}\text { Independent sample T } \\
\text { test }\end{array}$} \\
\cline { 3 - 4 } & & & $\mathrm{T}$ & $\mathrm{P}$ \\
\hline Group III (n=10) & $24-30$ & $26.75 \pm 1.95$ & -26.946 & $<0.000^{*}$ \\
\hline Group IV (n=10) & $44-48$ & $46.15 \pm 1.18$ & & \\
\hline
\end{tabular}

n: number; SD: standard deviation

* Significant at $\mathbf{P}<0.05$

\section{2- Toluidine blue results:}

Semithin sections of both control group and group II demonstrated sheets of lipid free hepatocytes with hepatic sinusoid inbetween. These hepatocytes are polygonal in shape, with central single or double pale nucleus and prominent nucleolus (Plate 1-A).

Ricin treated group showed microsteatotic hepatocytes with central single or double nuclei containing dark blue stained lipid droplets (steatosis) with dilated congested hepatic sinusoid and portal vein between them (Plate 2A, B).

Group IV showed hepatoctyes with microsteatos less than those detected in ricin treated group. Mildly congested dilated hepatic sinusoids were also detected (Plate 3- A).

\section{2- Electron microscopic results:}

Examination of ultrathin sections of liver obtained from control group and group II showed hepatocytes with hepatic sinusoids in between. The hepatocytes showed single or double euchromatic nuclei with prominent nucleoli. Their cytopalsm exhibited many mitocnodria and rough endoplasmic reticulum (RER) and glycogen granules (Plate 1- B, C).

Examination of sections obtained from ricin treated animals revealed hepatocytes with either euchromatic nuclei, shrunken hyperchromatic nuclei (apoptotic nucleus) or nuclei with marginated chromatin. Hugely dilated degranulated RER and electron dense mitochondria were detected. Moreover, abnormal lipid droplets and multiple vacuoles were noticed in the cytoplasm. Congested hepatic sinusoids were observed inbetween hepatocytes (Plate 2- C, D and E).

Examination of samples from group IV revealed hepatocytes with both single euchromatic nuclei and nuclei with marginated chromatin. Their cytoplasm exhibited slightly dilated RER, electron dense mitochondria and some vacuoles (Plate 3- B). 


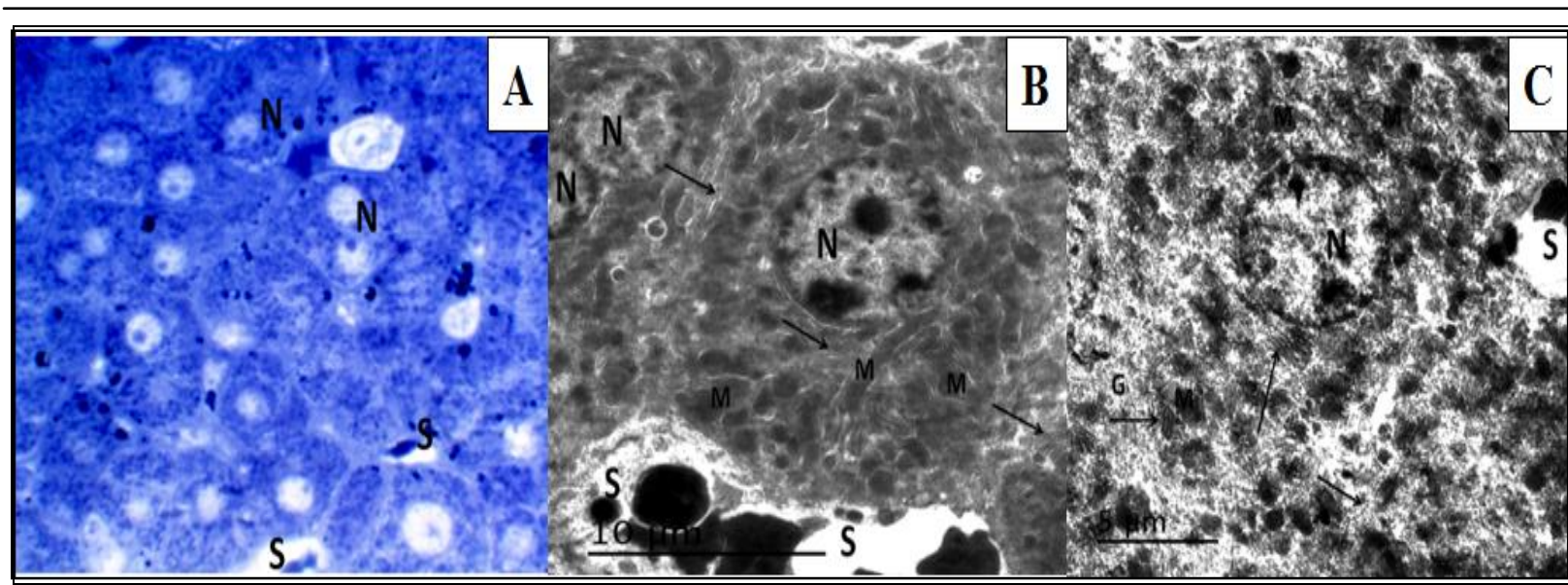

Plate (1): (A) A photomicrograph of semithin section of liver of group I shows sheets of polygonal hepatocytes with central single or double nuclei $(\mathrm{N})$ and narrow hepatic sinusoid $(\mathrm{S})$ between them [Toluidine blue X 1000]. (B \& C) Electron micrographs of ultrathin sections of liver of group I and group II show hepatocytes with single or double euchroamtic nuclei $(\mathrm{N})$ with prominent nucleoli. Their cytopalsm exhibits many mitocnodria $(\mathrm{M})$, rough endoplasmic reticulum (arrow) and glycogen granules (G). Note the nearby hepatic sinusoid (S).

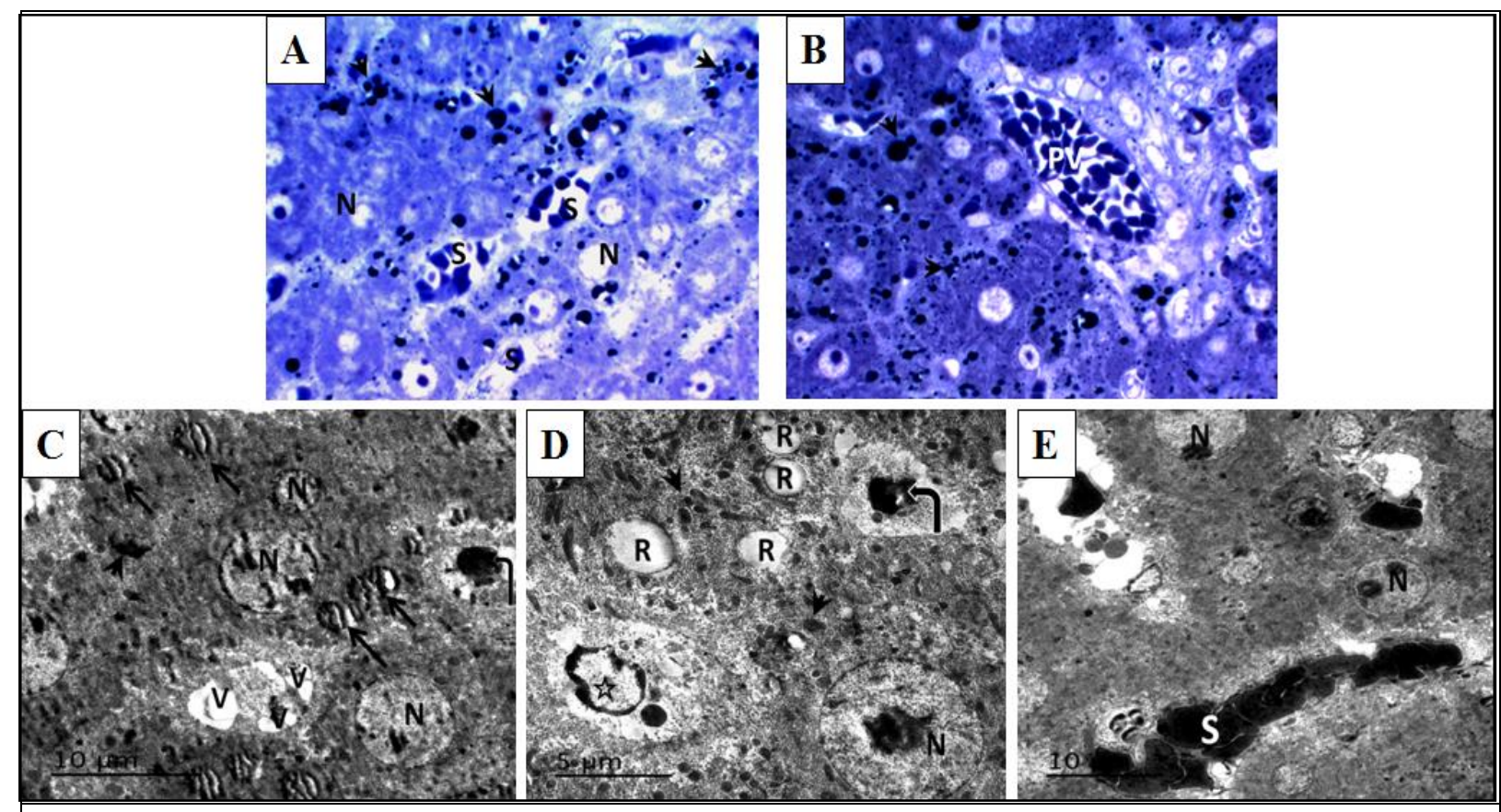

Plate (2): (A\& B) Photomicrographs of semithin section of liver of group III shows sheets of microsteatotic polygonal hepatocytes with central single or double nuclei (N) containing dark blue stained lipid droplets (arrow head) with dilated congested hepatic sinusoid (S) between them. Notice the dilated congested portal vein (PV) [Toluidine blue X1000]. (C, D\& E) Electron micrographs of ultrathin sections of liver of group III shows hepatocyte with either normal euchromatic (N), shrunken hyperchroamtic (aopototic) (curved arrow) or chromatin marginated nuclei (star) surrounded by hugely dilated degranulated rough endoplasmic reticulum (R), abnormal lipid droplets (arrow), electron dense mitochondria (arrow head) and multiple vacuoles (V). Notice the congested hepatic sinusoid (S) 


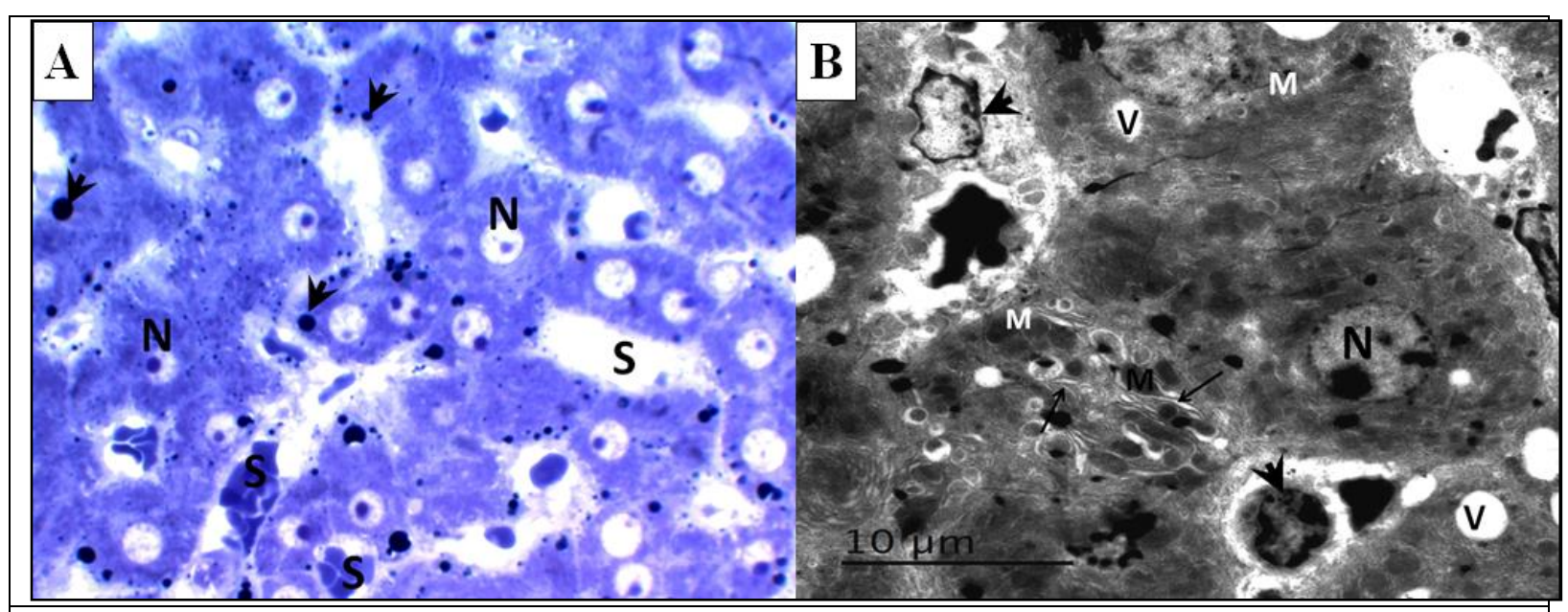

Plate (3): (A) A photomicrograph of semithin section of liver of group IV shows sheets of polygonal hepatocytes with central single or double nuclei $(\mathrm{N})$ and few steatotic cells containing few lipid droplets (arrow head). Notice the mildly dilated and congested hepatic sinusoid (S) between hepatocytes [Toluidine blue X 1000]. (B) Electron micrograph of ultrathin section of liver of group IV shows hepatocyte with either single euchromatic nucleus $(\mathrm{N})$ or nuclei with marginated chromatin (arrow head) surrounded by slightly dilated rough endoplasmic reticulum (arrow), electron dense mitochondria (M) and some cytoplamic vacuoles (V).

\section{DISCUSSION}

Ricin has a history of use as a weapon of war, terror and assassination for years (Buonocore, et al., 2011; Zhang, et al., 2015). Management of ricin toxicity is supportive and no antidote up till now is well established for ricin treatment. Such supportive measures are not so effective in rescuing lives of people who have received a lethal ricin dose (Bradberry, et al., 2003; Audi, et al., 2005; Dong, et al., 2015). Hence, the current study was conducted to confirm the previously reported toxic effects of ricin on the liver and to investigate ALA as a modulator of ricin toxicity.

Results of the present study revealed that subcutaneous injection of ricin has caused death within 24-30 hours. This could be attributed to rapid irreversible inhibition of protein synthesis causing cell death (Lord, et al., 1994; Buonocore, et al., 2011;
Dong, et al., 2015; Zhang, et al., 2015). Where ricin consists of catalytically active ricin A-chain (RTA) linked by a disulfide bond to a B-chain (RTB). Ricin toxicity resides in the A-chain, an $\mathrm{N}$-glycosidase that inhibits protein synthesis by cleaving one specific adenine from the $28 \mathrm{~S}$ RNA of the eukaryotic 60S ribosomal subunit (Stirpe, 2004; Sandvig, et al., 2010).

Preliminary studies revealed that ricin induces oxidative stress that results in lipid peroxidation, glutathione depletion, DNA single strand breaks and increased urinary excretion of carbonyl compounds. However, the mechanism involved in production of this oxidative stress is not fully under stood (Muldoon, et al., 1992; Muldoon, et al., 1994).

Consequently, it was noticed that ricin \& ALA treated animals showed statistically significant prolonged 
survival time. Such prolonged survival time could be explained in light of ALA critical role in mitochondrial energy metabolism (Shay, et al., 2009), through ALA mediated increase in antioxidant status and activities of mitochondrial dehydrogenase enzymes (Arivazhagan, et al., 2001), inhibition of cellular nitric oxide over-production and maintenance of antioxidant defense mechanisms (Abdel-Zaher, et al., 2008).

Such finding comes in line with Oda, et al., (1999) and Tamura, et al., (2002) who reported strong inhibition of ricin induced apoptetic cell death by antioxidant administration. Since, there was significant depletion of cellular glutathione in ricin treated cells. Furthermore, Sadani and Nadkarni, (1994) found that, administration of ricin at dose of 5 and $25 \mu \mathrm{g} / \mathrm{kg}$ body weight increases microsomal, mitochondrial and macrophage superoxide anion production in a dose dependent fashion. Additionally significant increase in glutathione peroxides level and reduction of nonprotein sulf-hydryl level following ricin intoxication are reported.

Over the last decade, several comparable research works have targeted ricin as a biothreat, with several trials to generate specific antidote treatment. Hashim, et al., (2008) have investigated the effect of some selected biologically active substances (dexamethasone and vitamin $\mathrm{E}$ ) on the modulation of ricin toxicity. They concluded that when animals were treated with dexamethasone they have shown longer survival time. Meanwhile, those treated with vitamin $E$ have survived for a shorter period of time.
Later on, Buonocore, et al., (2011)

have examined effectiveness of conventional or liposome-encapsulated $\mathrm{N}$-acetylcysteine (Lipo-NAC) in ameliorating ricin-induced hepatotoxicity. They concluded that, NAC administered in a liposomal form may serve as a potentially effective pharmacological agent in treatment of ricin-induced liver injuries. However, no report about modulating lethality was recorded in their study.

Recently, Zhang, et al., (2015) have generated a mutated and truncated ricin A-chain (mtRTA) vaccine antigen by E. coli strain. They recorded that there was no residual toxicity observed when compared to the recombinant RTA or native ricin. Furthermore, after subcutaneous vaccination with mtRTA three times at an interval of 2 weeks, the vaccinated mice developed a strong protective immune response that was wholly protective against $40 \times \mathrm{LD}_{50}$ of ricin intraperitoneal injection or $20 \times$ $\mathrm{LD}_{50}$ of ricin intratracheal spraying. Hence they recommended that mtRTA antigen has great potential to be a vaccine candidate for future application in humans.

Moreover, Dong, et al., (2015) has established a monoclonal antibody (mAb 4C13). They found that even at 6 $\mathrm{h}$ after ricin poisoning the $\mathrm{mAb} 4 \mathrm{C} 13$ could rescue more than $70 \%$ of the mice in their experiment. They also determined the relationship between mAb 4C13 dose and animal mortality. More than $50 \%$ the animals survived by $\mathrm{mAb} 4 \mathrm{C} 13$ at the dose of $25 \mathrm{ug} / \mathrm{kg}$. While when $100 \mathrm{ug} / \mathrm{kg}$ of mAb $4 \mathrm{C} 13$ was used, all poisoned mice survived with a single dose of antibody treatment.

Electron microscopic examination of liver specimens obtained from ricin 
treated group revealed ultra-structural changes that is more or less in line with data gathered from similar comparable research works (Bingen, et al., 1987; Vikas and Bhatia, 1990; Balint, 2000). Theses researches recorded changes in both RER \& smooth endoplasmic reticulum (SER), mitochondrial degeneration and heavily damaged kuppfer cells.

The exact mechanism(s) of ricin induced hepatic ultra-structure changes is still matter of argument and no conclusive mechanism has been obtained (Buonocore, et al., 2011). Yet, according to Vikas and Bhatia, (1990) ricin-induced RER dilatation could be considered as a sign of protein synthesis inhibition. It might be an adaptive process to increase the protein synthesis in response to polysomal RNA reduction associated with ricininduced cellular destruction. Neuberger, et al., (1980) supposed that, general toxins exposure induces hepatic fatty degeneration that could explain numerous lipid droplets appeared in the hepatocytes of the ricin treated animals.

Treatment of animals with ALA resulted in an ameliorating effect against ricin-induced hepatotoxicity. Briefly, ALA better preserved the cellular integrity of hepatocytes as indicated by less hepatocytes ultrastructural damage. The presence of normal mitochondria alternating with abnormal or even destructed ones could be explained according to Slautterback, (1965) who stated that whenever, there is destructed mitochondria, new healthy mitochondria will be formed as a compensatory mechanism to fulfill cellular needs.
The protective effects of ALA might be attributed to the abilities of the antioxidant to alter the early inflammatory responses by moderating the signal transduction of inflammatory cytokines, thereby modulating cellular activation (Sudheesh, et al., 2013). This result could be supported and explained by prolonged survival time in ALA \& ricin treated animals.

\section{CONCLUSION}

Ricin hepatotoxixity is confirmed by the ultra structure damage detected by the EM. Alpha lipoic acid is an antioxidant that proves to be beneficial in prolonging the survival time and decreasing the liver toxicity after ricin poisoning.

\section{RECOMMENDATIONS}

Further studies are recommended to detect the underlying mechanism of ricin hepatotoxicity and to find more protective substances against ricin toxicity.

\section{REFERENCES}

Abdel-Zaher, A. O., Abdel-Hady, R. H., Mahmoud, M. M. and Farrag, M. M. (2008): "The potential protective role of alphalipoic acid against acetaminopheninduced hepatic and renal damage". Toxicology 243: 261-270

Albretsen, J. C., Gwaltney-Brant, S. M. and Khan, S. A. (2000): "Evaluation of castor bean toxicosis in dogs: 98 cases". J Am Anim Hosp Assoc 36: 229-233

Arivazhagan, P., Ramanathan, K. and Panneerselvam, C. (2001): "Effect of DL-alpha-lipoic acid on mitochondrial enzymes in aged rats". Chem Biol Interact 138: 189198 
Audi, J., Belson, M., Patel, M., Schier, J. and Osterloh, J. (2005): "Ricin poisoning: a comprehensive review". JAMA 294: 2342-2351

Balali-Mood, M., Moshiri, M. and Etemad, L. (2013): "Medical aspects of bio-terrorism". Toxicon 69: 131-142

Balint, G. (2000): "Ultrastructural study of liver cell damage induced by ricin". Exp Toxicol Pathol 52: 413-417

Bingen, A., Creppy, E., Gut, J., Dirheimer, G. and Kirn, A. (1987): "The Kupffer cell is the first target in ricin-induced hepatitis". J Submicrosc Cytol 19: 247-256

Bozzola, J. J. and Russel, L. D. (1999): "Electron Microscopy Principles and Techniques for Biologists", $2^{\text {nd }}$ edition, Bozzola, J. J. and Russel, L. D. (editor), Jones and Bartlett Publisher, Boston. Pp: 16

Bradberry, S. M., Dickers, K. J., Rice, P., Griffiths, G. D. and Vale, J. A. (2003): "Ricin poisoning". Toxicol Rev 22: 65-70

Buonocore, C., Alipour, M., Omri, A., Pucaj, K., Smith, M. G. and Suntres, Z. E. (2011): "Treatment of ricin A-chain-induced hepatotoxicity with liposomeencapsulated N-acetylcysteine". J Drug Target 19: 821-829

David, J., Wilkinson, L. J. and Griffiths, G. D. (2009): "Inflammatory gene expression in response to sub-lethal ricin exposure in Balb/c mice". Toxicology 264: 119-130

Dawson-Saunders, B. and Trapp, $\mathbf{R}$. (2001): "Basic and clinical biostatics", $3^{\text {rd }}$ edition, DawsonSaunders, B. and Trapp, R. (editor),
McGrow Hill McGrow Hill Medical Publishing Division, Pp: $161-218$

Doan, L. G. (2004): "Ricin: mechanism of toxicity, clinical manifestations, and vaccine development. A review". J Toxicol Clin Toxicol 42: 201-208

Dong, N., Luo, L., Wu, J., Jia, P., Li, Q., Wang, Y., Gao, Z., Peng, H., Lv, M., Huang, C., Feng, J., Li, H., Shan, J., Han, G. and Shen, B. (2015): "Monoclonal antibody, $\mathrm{mAb} 4 \mathrm{C} 13$, an effective detoxicant antibody against ricin poisoning". Vaccine 33: 3836-3842

Dulundu, E., Ozel, Y., Topaloglu, U., Sehirli, O., Ercan, F., Gedik, N. and Sener, G. (2007): "Alphalipoic acid protects against hepatic ischemia-reperfusion injury in rats". Pharmacology 79: 163-170

El tomy, A. M. and Abo Hijleh, G. (1990): "Study of the toxic effect of castor been extract (Ricinus Communis) in albino rats ". J Legal Med Forensic Sci (Egyptian Society of Forensic Medicine and Science) 2: 1-11

Hashim, A. A., Elgohary, M. S., Saad, K. M., Ibrahim, W. M. and AboElfadl, A. A. (2008): "Study of The Toxic Effects of Ricin on The Target Organs and The Role of The Antidote". Egypt J Forensic Sci Appli Toxicol 8: 20-41

Kumar, O., Sugendran, K. and Vijayaraghavan, R. (2003): "Oxidative stress associated hepatic and renal toxicity induced by ricin in mice". Toxicon 41: 333-338

Kumar, O., Lakshmana Rao, P. V., Pradhan, S., Jayaraj, R., Bhaskar, A. S., Nashikkar, A. B. and Vijayaraghavan, R. (2007): "Dose dependent effect of ricin on 
DNA damage and antioxidant enzymes in mice". Cell Mol Biol (Noisy-le-grand) 53: 92-102

Lord, J. M., Roberts, L. M. and Robertus, J. D. (1994): "Ricin: structure, mode of action, and some current applications". FASEB J 8: 201-208

Makonnen, E., Zerihun, L., Assefa, G. and Rostom, A. A. (1999): "Antifertility activity of Ricinus communis seed in female guinea pigs". East Afr Med J 76: 335-337

Millard, C. B. and LeClaire, R. D. (2008): "Ricin and Related Toxins: Review and Perspective". In: Chemical Warfare Agents: Chemistry, Pharmacology, Toxicology, and Therapeutics, $2^{\text {nd }}$ edition, Romano, J. A., Lukey, B. J. and Salem, H. (editor), CRC Press Taylor \& Francis Group, Boca Raton. Pp:425

Mirakbari, S. M. (2015): "Hot charcoal vomitus in aluminum phosphide poisoning-A case report of internal thermal reaction in aluminum phosphide poisoning and review of literature". Indian J anaesth 59: 433

Muldoon, D. F., Bagchi, D., Hassoun, E. A. and Stohs, S. J. (1994): "The modulating effects of tumor necrosis factor alpha antibody on ricin-induced oxidative stress in mice". J Biochem Toxicol 9: 311318

Muldoon, D. F., Hassoun, E. A. and Stohs, S. J. (1992): "Ricin-induced hepatic lipid peroxidation, glutathione depletion, and DNA single-strand breaks in mice". Toxicon 30: 977-984

Muldoon, D. F. and Stohs, S. J. (1994): "Modulation of ricin toxicity in mice by biologically active substances". J Appl Toxicol 14: $81-86$

Neuberger, J., Davis, M. and Williams, R. (1980): "Long-term ingestion of paracetamol and liver disease". J R Soc Med 73: 701-707

Oda, T., Iwaoka, J., Komatsu, N. and Muramatsu, T. (1999):

"Involvement of $\mathrm{N}$-acetylcysteinesensitive pathways in ricin-induced apoptotic cell death in U937 cells". Biosci Biotechnol Biochem 63: 341-348

Sadani, G. and Nadkarni, G. (1994): "Role of antioxidant enzyme defence in sparing rat hepatocytes from toxicity of ricin at low dose". Indian J Exp Biol 32: 354-355

Sandvig, K., Torgersen, M. L., Engedal, N., Skotland, T. and Iversen, T. G. (2010): "Protein toxins from plants and bacteria: probes for intracellular transport and tools in medicine". FEBS Lett 584: 2626-2634

Schep, L. J., Temple, W. A., Butt, G. A. and Beasley, M. D. (2009): "Ricin as a weapon of mass terrorseparating fact from fiction". Environ Int 35: 1267-1271

Shay, K. P., Moreau, R. F., Smith, E. J., Smith, A. R. and Hagen, T. M. (2009): "Alpha-lipoic acid as a dietary supplement: molecular mechanisms and therapeutic potential". Biochim Biophys Acta 1790: 1149-1160

Singh, Y., Joshi, S. C., Satyawali, V. and Gupta, A. (2014): "Acute aluminium phosphide poisoning, what is new?". Egypt J Intern Med 26: 99

Slautterback, D. B. (1965): "Mitochondria in cardiac muscle cells of the canary and some other birds". J cell biol 24: 1-22 
Stirpe, F. (2004): "Ribosomeinactivating proteins". Toxicon 44: 371-383

Sudheesh, N., Ajith, T. and Janardhanan, K. (2013): "Hepatoprotective effects of DL- $\alpha$ lipoic acid and $\alpha$-Tocopherol through amelioration of the mitochondrial oxidative stress in acetaminophen challenged rats". Toxicol Mech Methods 23: 368376

Tamura, T., Sadakata, N., Oda, T. and Muramatsu, T. (2002): "Role of zinc ions in ricin-induced apoptosis in U937 cells". Toxicol lett 132: 141-151

Vikas and Bhatia, A. (1990): "Morphological changes in the liver on chronic administration of small doses of paracetamol in albino rats". Indian $\mathrm{J}$ Pathol Microbiol 33: 221-223
Woo, B. H., Lee, J. T. and Lee, K. C. (1998): "Purification of Sepharoseunbinding ricin from castor beans (Ricinus communis) by hydroxyapatite chromatography". Protein Expr Purif 13: 150-154

Yousef, M. I., Soliman, N. F. and EIDemerdash, F. M. (2015): "Aluminium Phosphide-induced Hepato-nephrotoxicity and Oxidative Damage in Rats: The Protective Effect of $\alpha$-lipoic Acid". The Open Conference Proceedings Journal 6: 18-23

Zhang, T., Yang, H., Kang, L., Gao, S., Xin, W., Yao, W., Zhuang, X., Ji, B. and Wang, J. (2015): "Strong protection against ricin challenge induced by a novel modified ricin A-chain protein in mouse model". Hum Vaccin Immunother 11: 1779-1787 


\section{الملخص العربي}

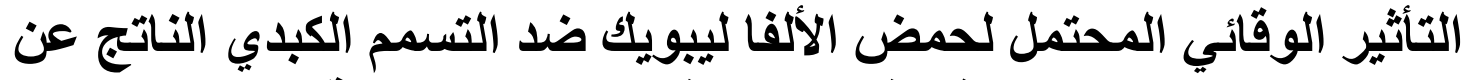

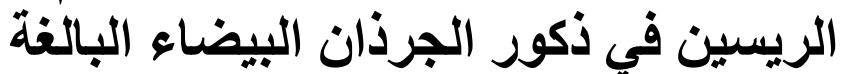

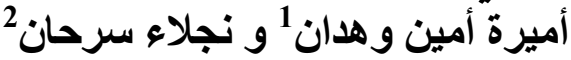

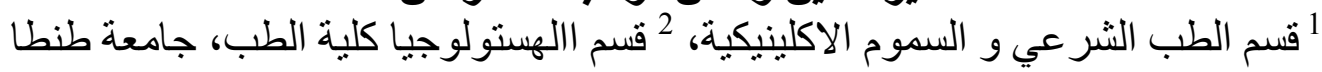

المقدمة: الريسين هو واحد من أقوى السموم النباتية القاتلة المعروفة. فهو يؤدي الىى الاجهاد التأكسدي و

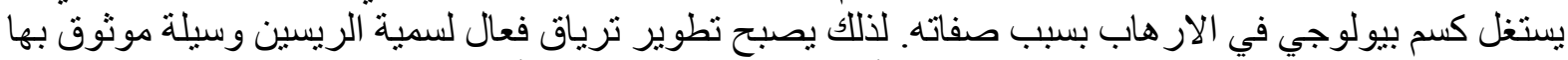

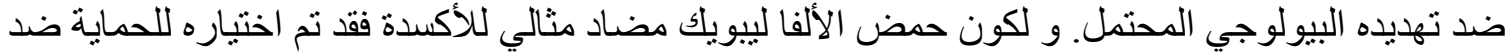

الهُف من البحث: أجريت الدر اسة الحالية لاثبات التأثير السام للريسين على الكبد باستخدام المجهر

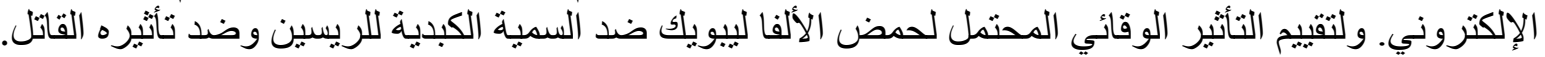

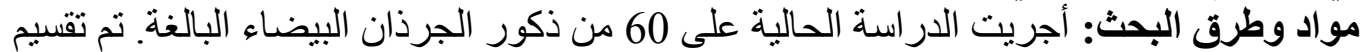

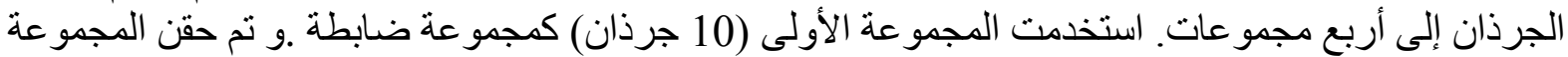

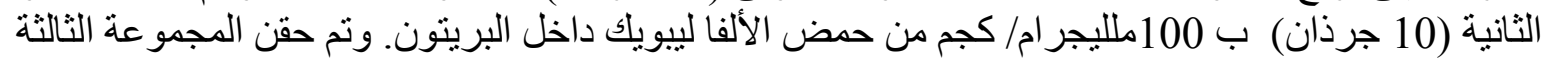

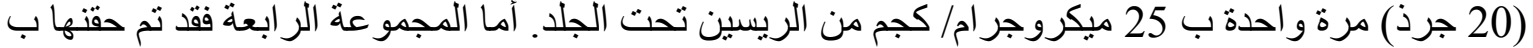

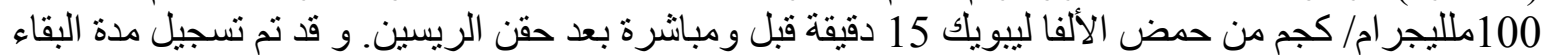

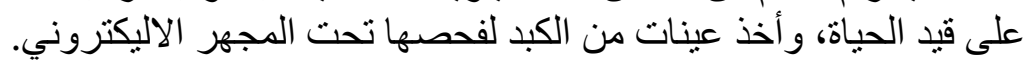

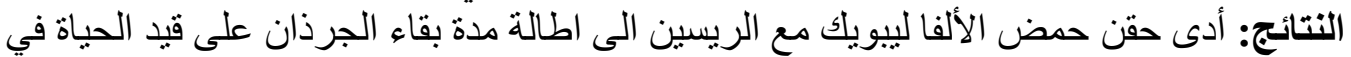

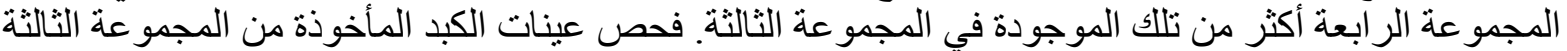

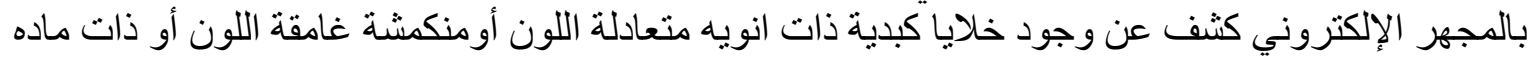

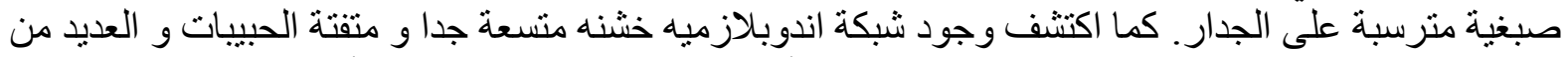

قطر ات الدهون و ميتوكوندريا كثيفة الإلكترونات. و قد أدى اعطاء الحيوانات حمض الألفا ليبويك الى ظهور

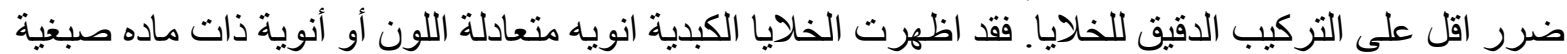

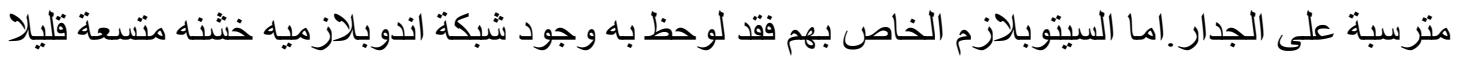

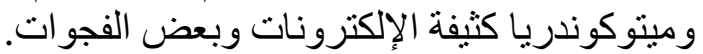

الاستتتاج: وقد خلص إلى أن الريسين هو مادة سامة للكبد تتسبب في ضرر للتركيب الدقيق. و علاوة على ذلك، فقد أثبت حمض الألفا ليبو يك انه مفيد في إطالة مدة البقاء على قيد الحياة وتقليل التأثثير السام للريسين واني على الكبد. التوصيات: ينصح بالمزيد من الدر اسات للكثف عن الآلية الكامنة ور اء تسمم الكبد بالريسين و إيجاد مو اد أكثر وقائية ضد سمية الريسين باتصنين 